\title{
Balanço de compostos nitrogenados e produção de proteína microbiana em novilhas leiteiras alimentadas com palma forrageira, bagaço de cana-de- açúcar e uréia associados a diferentes suplementos ${ }^{1}$
}

\author{
Ricardo Alexandre Silva Pessoa ${ }^{2^{*}}$, Maria Ignez Leão ${ }^{3}$, Marcelo de Andrade Ferreira ${ }^{4}$, Sebastião \\ de Campos Valadares Filho ${ }^{3}$, Rilene Ferreira Diniz Valadares ${ }^{5}$, Augusto César de Queiroz ${ }^{3}$
}

${ }^{1}$ Trabalho parcialmente financiado pelo CNPq.

2 Programa de Pós-graduação em Zootecnia - UFV.

${ }^{3}$ Departamento de Zootecnia - UFV.

${ }^{4}$ Departamento de Zootecnia - UFRPE.

${ }^{5}$ Departamento de Veterinária - UFV.

RESUMO - Objetivou-se avaliar o efeito da associação de palma forrageira ao bagaço de cana-de-açúcar e à uréia sobre o balanço de compostos nitrogenados e a produção de proteína microbiana em novilhas leiteiras recebendo ou não suplemento. Foram utilizadas 25 novilhas da raça Girolando, com peso vivo médio inicial de $227 \mathrm{~kg}$, confinadas, distribuídas em delineamento experimental de blocos ao acaso, estabelecidos de acordo com o peso dos animais. A ração controle (sem suplemento) foi composta de 64,0\% de palma forrageira, 30,0\% de bagaço de cana-de-açúcar, 4,0\% de mistura uréia:sulfato de amônio (9:1) e 2,0\% de mistura mineral, com base na matéria seca (MS), e as rações experimentais, de 57,0\% de palma forrageira, $26,0 \%$ de bagaço de cana-de-açúcar, 3,5\% de mistura uréia:sulfato de amônio, 1,8\% de mistura mineral e 11,7\% de suplemento (0,5\% do PV dos animais). Os suplementos testados foram: farelo de trigo, farelo de soja, farelo de algodão ou caroço de algodão. O balanço de nitrogênio não foi influenciado pelas dietas e apresentou valor médio de 49,3 g/dia. A suplementação com farelo de algodão ou com farelo de soja aumentou a excreção de nitrogênio na urina, a concentração de uréia e nitrogênio uréico no plasma e a excreção urinária de uréia e nitrogênio uréico. A associação da palma forrageira ao bagaço de cana-de-açúcar e à uréia, sem o uso de suplementos, permite eficiência de síntese microbiana de 105 gPBmic/kg de NDT consumido. A suplementação com caroço de algodão proporciona maior excreção urinária de alantoína e derivados de purina e melhor eficiência de síntese microbiana, portanto, é a mais indicada nestas condições.

Palavras-chave: fibra, nitrogênio não-protéico, Opuntia ficus, síntese microbiana, suplementação

\section{Nitrogenous compounds balance and microbial protein production in crossbred heifers fed forage cactus, sugar cane bagasse and urea associated to different supplements}

\begin{abstract}
The objective of this work was to evaluate the effect of association of forage cactus to sugar cane bagasse and urea on nitrogenous compounds balance and microbial protein synthesis in milk heifers supplemented or not. Twentyfive Holstein-Gir crossbred heifers with average of $227 \mathrm{~kg}$ of LW were used, kept in feedlot system and assigned to a randomized block design, established in accordance with the weight of animals. The control ration was composed of $64.0 \%$ of forage cactus, $30.0 \%$ of sugar cane bagasse, $4.0 \%$ of urea:ammonium sulphate mixture (9:1) and $2.0 \%$ of mineral mixture, in DM basis. The heifers were supplemented based on the live weight ( $0.5 \%$ of the $\mathrm{LW})$. The supplements had characterized the treatments, together with the control treatment. The tested supplements were: wheat meal, soybean meal, cottonseed meal or whole cottonseed. The proportion of ingredients in experimental rations for supplemented animals was: $57.0 \%$ of forage cactus, $26.0 \%$ of sugar cane bagasse, $3.5 \%$ of urea:ammonium sulphate mixture, $1.8 \%$ of mineral mixture and $11.7 \%$ of supplement. The nitrogen balance was not influenced by treatments, presenting average value of $49.3 \mathrm{~g} / \mathrm{day}$. The cottonseed meal or soybean meal supplementation increased the nitrogen urinary excretion, the urea concentration and urea nitrogen in the serum and the urea urinary excretion and urea nitrogen. The association of forage cactus to sugar cane bagasse and urea, without the use of supplements allowed microbial synthesis efficiency of 105.0 gCPmic/kg of consumed TDN. The whole cottonseed supplementation provided greater alantoin and purine derivatives urinary excretion and better microbial synthesis efficiency, being, therefore, the most indicated in such conditions.
\end{abstract}

Key Words: fiber, microbial synthesis, nonprotein nitrogen, Opuntia fícus, supplementation 


\section{Introdução}

O estabelecimento de um sistema de recria eficiente tem sido um desafio para a maioria dos produtores de leite. O manejo ineficiente tem levado à idade tardia ao primeiro parto, o que contribui para baixa produtividade do rebanho e vida útil da fêmea. Altas taxas de mortalidade e morbidade de animais em crescimento são verificadas em sistemas não-racionais, em decorrência do inadequado manejo nutricional. A idade à puberdade é uma característica que depende diretamente da nutrição, e o atendimento das exigências nutricionais pode contribuir para diminuir a idade ao primeiro estro.

Há poucas informações na literatura a respeito do uso de palma forrageira em dietas para bovinos em crescimento. Entretanto, vários estudos comprovam a importância da palma na nutrição de vacas em lactação e indicam a viabilidade de sua utilização como alimento-base para animais de origem leiteira em fase de recria. As principais limitações dessa cactácea, como compostos nitrogenados e fibra em detergente neutro, podem ser reduzidas com a inclusão na dieta de alimentos de baixo custo e de fácil aquisição, como o bagaço de cana e a uréia.

A avaliação do balanço de nitrogênio no animal e da concentração de uréia no soro e na urina permite a obtenção de informações a respeito da nutrição protéica dos ruminantes, o que pode ser importante para evitar prejuízos produtivos, reprodutivos e ambientais, decorrentes do fornecimento de quantidades excessivas de proteína ou da inadequada sincronia energia-proteína no rúmen.

O suprimento de aminoácidos a partir da proteína microbiana é fundamental para o metabolismo protéico dos ruminantes, uma vez que a maior parte dos aminoácidos absorvidos no intestino delgado é proveniente da proteína microbiana. A eficiência de produção microbiana e o fluxo microbiano são fatores determinantes da quantidade de proteína microbiana que alcança o intestino delgado. De acordo com o NRC (2001), a proteína sintetizada pelos microrganismos ruminais possui excelente perfil aminoacídico e composição pouco variável. Dessa forma, o estudo dos mecanismos de síntese protéica microbiana e dos fatores relacionados são de grande importância.

Objetivou-se avaliar o balanço de compostos nitrogenados e a produção de proteína microbiana em novilhas leiteiras mantidas com dietas à base de palma forrageira, bagaço de cana-de-açúcar e uréia associados ou não a suplementos tradicionalmente utilizados na alimentação de vacas leiteiras.

\section{Material e Métodos}

O experimento foi conduzido na Estação Experimental de Arcoverde, pertencente ao Instituto Agronômico de Pernambuco, no período de maio a agosto de 2005. A cidade de Arcoverde está localizada no Sertão de Pernambuco, na latitude $08^{\circ} 25^{\prime} 00^{\prime \prime}$ sul, longitude $37^{\circ} 04^{\prime} 00^{\prime \prime}$ oeste e altitude de $664 \mathrm{~m}$, com temperatura mínima de $18,3^{\circ} \mathrm{C}$ e máxima de 29, $2^{\circ} \mathrm{C}$ (Encarnação, 1980).

Foram utilizadas 25 novilhas leiteiras da raça Girolando, com peso vivo médio inicial de $227 \mathrm{~kg}$, mantidas em regime de confinamento, em delineamento experimental de blocos ao acaso, estabelecidos de acordo com o peso dos animais, com cinco blocos e cinco rações. Previamente ao início do período experimental, as novilhas receberam tratamento contra endoparasitos, ectoparasitos e suplementação vitamínica (ADE). Durante os últimos 21 dias que antecederam o estudo, os animais receberam alimentação similar à do período experimental com objetivo de reduzir o ganho compensatório.

A ração controle (sem suplemento) foi composta de $64,0 \%$ de palma forrageira, 30,0\% de bagaço de cana-deaçúcar in natura, 4,0\% de mistura uréia:sulfato de amônio (9:1), 2,0\% de mistura mineral, com base na matéria seca (MS), e suplementação com base no peso vivo $(0,5 \%$ do PV), de modo que os suplementos (farelo de trigo, farelo de soja, farelo de algodão ou caroço de algodão) caracterizaram os tratamentos, avaliados em comparação a um tratamento controle. A proporção de ingredientes nas rações experimentais dos animais sob suplementação foi de $57,0 \%$ de palma forrageira, $26,0 \%$ de bagaço de canade-açúcar, 3,5\% de mistura uréia:sulfato de amônio (9:1), $1,8 \%$ de mistura mineral e $11,7 \%$ de suplemento, com base na MS. A espécie de palma forrageira utilizada foi a Opuntia ficus indica Mill, cv. Gigante, picada em máquina forrageira apropriada e fornecida aos animais na forma de ração completa (Tabela 1).

Durante 84 dias, divididos em três períodos de 28 dias, foram realizadas coletas de dados e amostras para avaliação da eficiência de utilização dos compostos nitrogenados, nitrogênio uréico no plasma, excreção urinária de nitrogênio, balanço de nitrogênio e síntese de proteína microbiana ruminal.

Amostras spot de urina foram coletadas uma vez no segundo e terceiro períodos do experimento, aproximadamente 4 horas após a alimentação, durante micção espontânea. Da urina coletada, após homogeneização e filttragem, foram obtidas alíquotas de $10 \mathrm{~mL}$, diluídas em $40 \mathrm{~mL}$ de ácido sulfúrico $0,036 \mathrm{~N}$, conforme descrito por Valadares 
Tabela 1 - Composição nutricional da ração controle e dos ingredientes

\begin{tabular}{|c|c|c|c|c|c|c|c|}
\hline & $\begin{array}{c}\text { Ração } \\
\text { controle }\end{array}$ & $\begin{array}{l}\text { Palma } \\
\text { forrageira }\end{array}$ & $\begin{array}{l}\text { Bagaço de } \\
\text { cana }\end{array}$ & $\begin{array}{l}\text { Farelo de } \\
\text { trigo }\end{array}$ & $\begin{array}{c}\text { Caroço de } \\
\text { algodão }\end{array}$ & $\begin{array}{l}\text { Farelo de } \\
\text { algodão }\end{array}$ & $\begin{array}{c}\text { Farelo de } \\
\text { soja }\end{array}$ \\
\hline Matéria seca (\%) & 13,72 & 10,55 & 25,72 & 88,30 & 87,00 & 87,30 & 85,20 \\
\hline Extrato etéreo (\% MS) & 2,05 & 2,35 & 1,83 & 4,02 & 21,08 & 0,91 & 1,94 \\
\hline $\mathrm{FDN}_{\mathrm{CP}}(\% \mathrm{MS})$ & 42,77 & 28,70 & 81,22 & 42,32 & 45,13 & 32,27 & 10,01 \\
\hline Carboidratos não-fibrosos(\% MS) & 23,85 & 52,41 & 10,22 & 31,19 & 8,07 & 20,43 & 31,84 \\
\hline
\end{tabular}

FDNcp: fibra em detergente neutro corrigida para cinzas e proteína.

et al. (1999). Quando necessário, as amostras tiveram $\mathrm{pH}$ ajustado para abaixo de 3, para evitar destruição bacteriana dos derivados de purina, e foram acondicionadas em recipientes plásticos identificados e congeladas para posteriores análises de uréia, nitrogênio total, creatinina, ácido úrico e alantoína.

O volume urinário total diário foi estimado dividindo-se as excreções urinárias diárias de creatinina pelos valores observados de concentração de creatinina na urina, segundo Valadares Filho \& Valadares (2001). A excreção urinária diária de creatinina foi estimada por meio da equação proposta por Chizzotti (2004): EC (g/dia) $=32,27-0,01093$ * PV (kg), uma vez que, em animais em crescimento, a porcentagem de tecido muscular varia de acordo com o peso vivo e, conseqüentemente, a excreção de creatinina (mg/kg de PV) pode ser alterada.

Amostras de sangue foram coletadas uma vez, no segundo e terceiro períodos do experimento, via punção da veia jugular, utilizando-se tubos de ensaio com anticoagulante. Imediatamente, procedeu-se à centrifugação a 5.000 rpm por 15 minutos e, posteriormente, retiraram-se amostras de plasma, que foram acondicionadas e congeladas a $-15^{\circ} \mathrm{C}$ para posteriores análises de uréia.

O balanço de compostos nitrogenados foi obtido pela diferença entre o total de nitrogênio ingerido e o total excretado nas fezes e na urina. A determinação do nitrogênio total nas fezes e na urina foi realizada segundo metodologia descrita por Silva \& Queiroz (2002).

As análises de alantoína na urina foram realizadas pelo método colorimétrico, segundo a metodologia proposta por Fujihara et al. (1987), descrito por Chen \& Gomes (1992). As análises e determinações de creatinina, ácido úrico e uréia foram realizadas utilizando-se kits comerciais (Doles). A excreção total de derivados de purina (DP) foi calculada pela soma das quantidades de alantoína e ácido úrico excretadas na urina, expressas em mmol/dia.

As purinas absorvidas (X, mmol/dia) foram calculadas a partir da excreção de DP (Y, mmol/dia), por meio da equação $\mathrm{Y}=0,84 \mathrm{X}+0,236 \mathrm{PV}^{0,75}$, em que 0,84 é a recupe- ração de purinas absorvidas como derivados de purinas e 0,236 PV ${ }^{0,75}$, a contribuição endógena para excreção de purinas (Orellana Boero et al., 2001).

A síntese de compostos nitrogenados microbianos no rúmen (Y, gN/dia) foi calculada em relação às purinas absorvidas ( $\mathrm{X}, \mathrm{mmol} / \mathrm{dia}$ ), por meio da equação $\mathrm{Y}=(70 \mathrm{X}) /(0,83 \times 0,134 \times 1000)$ (Chen \& Gomes, 1992), em que 70 representa o nitrogênio nas purinas $(\mathrm{mgN} / \mathrm{mmol})$; 0,83 , a digestibilidade intestinal das purinas microbianas e 0,134, a relação N-purina:N-total nas bactérias (Valadares et al., 1999).

Os resultados foram avaliados por meio de análise de variância e, para comparação entre as médias, utilizou-se o teste de Student-Newman-Keuls (SNK) com nível de significância de 5\%, por meio do Sistema de Análises Estatísticas e Genéticas - SAEG (UFV, 1998).

\section{Resultados e Discussão}

As concentrações de proteína bruta dietética foram em média de 13,4; 13,7; 14,4; 16,4 e 17,3\% da matéria seca para as dietas controle e com os suplementos farelo de trigo, caroço de algodão, farelo de algodão ou farelo de soja, respectivamente. A ingestão de nitrogênio foi maior $(\mathrm{P}<0,05)$ entre os animais que receberam suplementação com farelo de algodão ou com farelo de soja (Tabela 2), provavelmente em virtude da maior concentração de proteína bruta na dieta dos animais mantidos com a dieta com farelo de soja ou farelo de algodão, como reflexo dos maiores teores de nitrogênio nesses suplementos.

$\mathrm{O}$ consumo de nitrogênio entre os animais alimentados com a ração controle foi semelhante $(P>0,05)$ ao daqueles mantidos com a dieta com farelo de trigo ou com caroço de algodão, uma vez que essas dietas apresentaram teores de proteína bruta muito próximos. Aumento no consumo de nitrogênio com o aumento do teor de proteína bruta da dieta tem sido observado em vários estudos (Valadares et al., 1997; Ítavo et al., 2002; Rennó et al., 2008; Cavalcante et al., 2006). 
Tabela 2 - Ingestão de compostos nitrogenados e balanço de nitrogênio

\begin{tabular}{|c|c|c|c|c|c|c|}
\hline Item & \multicolumn{5}{|c|}{ Dieta experimental } & CV (\%) \\
\hline $\mathrm{N}$ nas fezes ${ }^{1}$ & $32,40 \mathrm{~b}$ & $36,88 \mathrm{ab}$ & $45,20 a$ & $50,30 a$ & 41,43ab & 16,2 \\
\hline $\mathrm{N}$ na urina ${ }^{1}$ & $75,12 b$ & $82,81 \mathrm{~b}$ & $113,66 \mathrm{a}$ & $111,55 a$ & $77,23 b$ & 26,2 \\
\hline Balanço de nitrogênio ${ }^{1}$ & 36,08 & 44,31 & 62,14 & 58,55 & 45,34 & 25,6 \\
\hline
\end{tabular}

Médias na linha seguidas de letras diferentes diferem $(\mathrm{P}<0,05)$ pelo teste SNK; Nitrogênio (N); ${ }^{1}$ g/dia; ${ }^{2}$ Balanço de N/Ingestão de nitrogênio; CV - coeficiente de variação.

Maior excreção de nitrogênio nas fezes $(\mathrm{P}<0,05)$ foi observada nos animais mantidos com as dietas com farelo de algodão ou com farelo de soja, em comparação à dieta controle, fato relacionado à magnitude do consumo de nitrogênio. Os animais alimentados com a ração controle apresentaram excreção de nitrogênio nas fezes semelhante $(\mathrm{P}>0,05)$ à daqueles alimentados com as rações com farelo de trigo ou caroço de algodão.

A excreção de nitrogênio na urina foi maior $(\mathrm{P}<0,05)$ nos animais alimentados com as rações com farelo de soja ou farelo de algodão. Segundo Van Soest (1994), a excreção de nitrogênio na urina é maior quando a concentração de proteína bruta na dieta e a ingestão de nitrogênio pelo animal aumentam. Valadares et al. (1997) também observaram maior excreção de nitrogênio na urina de novilhos zebuínos em função do aumento do teor protéico da dieta.

O balanço de nitrogênio não foi influenciado $(\mathrm{P}>0,05)$ pelos suplementos e apresentou valor médio de 49,3 g/dia, o que pode estar relacionado ao aumento no consumo de nitrogênio e nas excreções de nitrogênio nas fezes e na urina. A porcentagem de nitrogênio retido em relação ao nitrogênio consumido também não foi influenciada $(\mathrm{P}>0,05)$ pelas dietas.

Foram observadas diferenças significativas $(\mathrm{P}<0,05)$ para concentração de uréia e nitrogênio uréico no soro, que foi maior nos animais alimentados com a ração com farelo de algodão ou farelo de soja (Tabela 3).
O comportamento observado para concentração de uréia e nitrogênio uréico no soro está de acordo com os níveis de proteína bruta nas dietas, o que ocasionou maior consumo de nitrogênio para essas dietas (Tabela 2). Valadares et al. (1997)e Valadares et al. (1999) demonstraram que a concentração sérica de uréia está positivamente relacionada à ingestão de nitrogênio. Os teores de nitrogênio uréico no soro têm sido utilizados para obtenção de informações sobre o perfil da nutrição protéica de ruminantes, envolvendo suas respostas metabólicas a determinadas dietas (Chizzotti et al., 2006). Nesse sentido, a concentração sérica de uréia está relacionada à utilização da proteína bruta da dieta e maiores concentrações podem caracterizar ineficiência na utilização da proteína e maiores perdas de energia. Rennó et al. (2000) observaram aumento linear na concentração plasmática de uréia com o incremento dos níveis de proteína bruta na dieta. Valadares et al. (1997), em pesquisa com novilhos alimentados com dietas contendo 7,0; 9,5; 12,0 e 14,5\% de proteína bruta, observaram influência do teor protéico da dieta sobre os níveis de nitrogênio uréico no plasma, que foram de 8,1; 9,1; 15,7 e 19,5 mg/dL, respectivamente. Butler et al. (1995) sugeriram que, quando o nitrogênio uréico no soro excede 19-20 mg/dL, a taxa de concepção pode ser reduzida em aproximadamente $20,0 \%$.

A maior excreção urinária de uréia e nitrogênio uréico $(\mathrm{P}<0,05)$ foi observada nos animais que receberam suplementação com farelo de algodão ou com farelo de soja.

Tabela 3 - Concentração no soro e excreção urinária de uréia e N-uréico

\begin{tabular}{|c|c|c|c|c|c|c|}
\hline \multirow[t]{2}{*}{ Item } & \multicolumn{5}{|c|}{ Dieta experimental } & \multirow[t]{2}{*}{ CV (\%) } \\
\hline & Controle & $\begin{array}{c}\text { Farelo de } \\
\text { trigo }\end{array}$ & $\begin{array}{c}\text { Farelo de } \\
\text { soja }\end{array}$ & $\begin{array}{c}\text { Farelo de } \\
\text { algodão }\end{array}$ & $\begin{array}{l}\text { Caroço de } \\
\text { algodão }\end{array}$ & \\
\hline Uréia no soro (mg/dL) & $32,55 c$ & $28,85 c$ & $38,97 b$ & $43,41 \mathrm{a}$ & $33,08 c$ & 13,6 \\
\hline N-uréico no soro (mg/dL) & $15,17 \mathrm{c}$ & $13,45 c$ & $18,16 b$ & $20,23 a$ & $15,41 \mathrm{c}$ & 13,6 \\
\hline Uréia na urina (g) & $55,03 b$ & $44,06 b$ & $76,34 a$ & $84,71 \mathrm{a}$ & $53,95 b$ & 19,1 \\
\hline N-uréico na urina (g) & $25,64 b$ & $20,53 b$ & $35,57 a$ & $39,47 a$ & $25,14 b$ & 19,1 \\
\hline Uréia na urina (mg/kgPV) & $237,46 b$ & $193,85 c$ & 299,49a & $317,96 a$ & $221,05 b$ & 15,8 \\
\hline N-uréico na urina (mg/kgPV) & $110,65 b$ & $90,34 c$ & $139,56 a$ & $148,17 \mathrm{a}$ & $103,01 b$ & 15,8 \\
\hline
\end{tabular}

Médias na linha seguidas de letras diferentes diferem $(\mathrm{P}<0,05)$ pelo teste $\mathrm{SNK}$; CV = coeficiente de variação. 
Quanto maior o teor protéico da dieta, maior a produção de amônia e maiores as concentrações de uréia no soro e as perdas nitrogenadas pela urina. Neste caso, o efeito do maior consumo de nitrogênio nos animais alimentados com as rações com farelo de algodão ou farelo de soja resultou em maiores concentrações plasmáticas e excreção de uréia na urina. A excreção de uréia representa elevado custo biológico e desvio de energia para manutenção das concentrações corporais de nitrogênio em níveis nãotóxicos aos animais. A conversão da amônia em uréia custa ao animal 12 kcal/g de nitrogênio (Van Soest, 1994).

Neste estudo, a excreção urinária de uréia refletiu a concentração de uréia no soro. Comportamento semelhante foi descrito por Teixeira et al. (2007), que não observaram diferenças na concentração de uréia no soro, mas verificaram efeito linear sobre a excreção de uréia urinária, atribuído ao aumento no consumo de nitrogênio total. Magalhães et al. (2005) também sugeriram que a excreção urinária de uréia acompanha a concentração plasmática de uréia. Chizzotti et al. (2006), em pesquisa com novilhas leiteiras, encontraram excreção urinária de nitrogênio uréico de 22,4 g/dia para animais com 235 kg consumindo ração com aproximadamente $11,0 \%$ de proteína bruta. Valadares et al. (1997) observaram 27,4 g/dia de nitrogênio uréico excretado na urina de zebuínos alimentados com dietas contendo $12,0 \%$ de proteína bruta.

$\mathrm{O}$ atendimento das exigências protéicas dos animais, por meio da correta formulação de dietas, é uma das formas de evitar que excessos de uréia sejam excretados para o ambiente, medida importante para reduzir o impacto ambiental nos sistemas de produção e que evita prejuízos financeiros, uma vez que a proteína verdadeira é o nutriente de maior custo na dieta dos ruminantes.

Depreende-se que a suplementação com farelo de algodão ou com farelo de soja na proporção de $0,5 \%$ do peso vivo em dietas à base de palma forrageira, bagaço de cana-de-açúcar e uréia para novilhas leiteiras resulta em maior consumo de nitrogênio e aumento na concentração de uréia plasmática e na excreção de compostos nitrogenados na urina.

Os animais que receberam suplementação com farelo de trigo ou farelo de algodão apresentaram excreção urinária de alantoína e derivados de purinas semelhantes $(\mathrm{P}>0,05)$, porém inferiores $(\mathrm{P}<0,05)$ à dos animais alimentados com as rações com caroço de algodão ou farelo de soja (Tabela 4).

A quantificação da síntese de proteína microbiana em bovinos pelo método da excreção urinária de derivados de purina indica que o fluxo duodenal de ácidos nucléicos é essencialmente de origem microbiana e, após a digestão intestinal dos nucleotídeos de purinas, as bases adenina e guanina são catabolizadas e excretadas proporcionalmente na urina como derivados de purinas, principalmente alantoína, e também ácido úrico (Perez et al., 1996).

O balanceamento entre o suprimento de nitrogênio e energia para os microrganismos ruminais tem sido proposto como mecanismo para aumentar a captura do nitrogênio ruminalmente degradável e melhorar o crescimento microbiano. Nesse sentido, os animais receberam a mesma dieta basal e, independentemente da dieta, apresentaram consumo de nutrientes digestíveis totais (NDT) em média de 3,54; 4,08; 4,44; 4,80 e 4,03 kg de NDT/dia para ração controle e aquelas com farelo de trigo, farelo de soja, farelo de algodão e caroço de algodão, respectivamente, suficientes para o atendimento das exigências nutricionais.

Não foram observados efeitos significativos $(\mathrm{P}>0,05)$ das dietas sobre as excreções de ácido úrico (em média 19,4 mmol/dia). Na avaliação da relação alantoína: derivados de purina, os animais que receberam suplemento com caroço de algodão apresentaram maior média $(\mathrm{P}<0,05)$ em comparação àqueles que receberam o suplemento com farelo de soja. Os valores obtidos neste estudo foram

Tabela 4 - Excreção urinária de derivados de purina, purinas absorvidas, síntese e eficiência microbiana

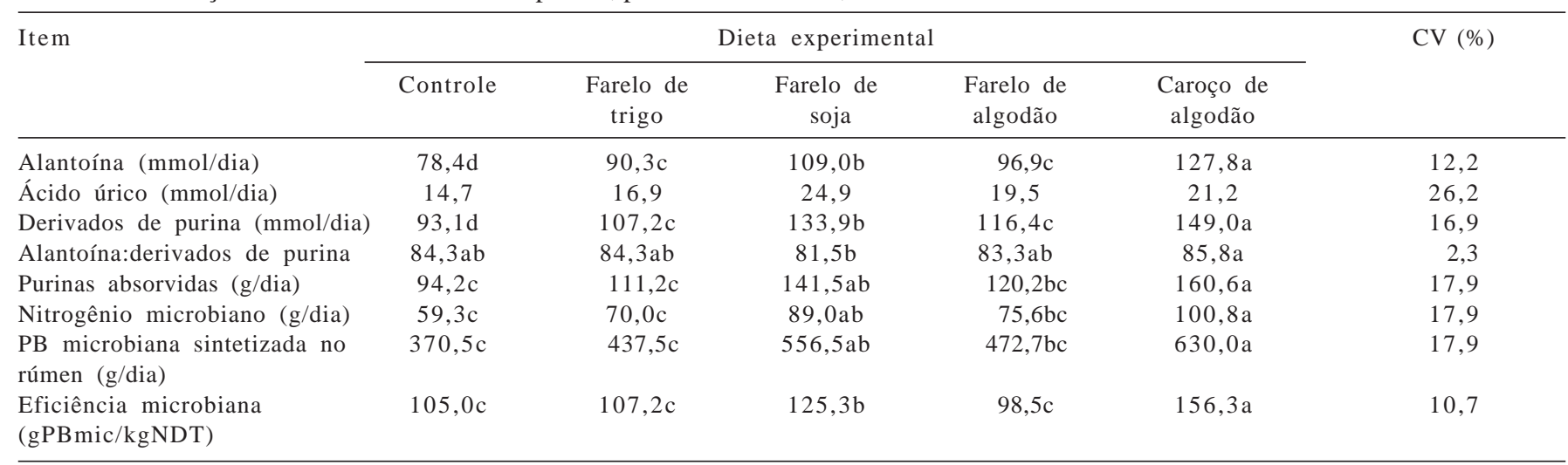

Médias na linha seguidas de letras diferentes diferem $(\mathrm{P}<0,05)$ pelo teste $\mathrm{SNK}$; CV = coeficiente de variação. 
próximos ao observado por Verbic et al. (1990), em torno de 85,0\%, e inferiores aos observados por Chizzotti et al. (2006), 91,8\%; Leão (2002), 87,9\%, e Teixeira et al. (2007), 89,7\%.

Os animais alimentados com a ração com caroço de algodão apresentaram médias de 160,6; 100,8 e 630,0 g/dia para purinas absorvidas, produção de nitrogênio microbiano e produção de proteína bruta microbiana, respectivamente, superiores $(\mathrm{P}<0,05)$ às médias obtidas com as rações com farelo de trigo, farelo de algodão e controle e semelhantes $(\mathrm{P}>0,05)$ às observadas com farelo de soja. O comportamento dos animais que não receberam suplemento foi semelhante $(\mathrm{P}>0,05)$ ao daqueles alimentados com a dieta com farelo de algodão ou com o farelo de trigo.

A eficiência de síntese microbiana foi maior $(\mathrm{P}<0,05)$ para a dieta com caroço de algodão (156,3 g de PB microbiana/kg de NDT consumido). Entre os aspectos de maior importância em dietas à base de palma forrageira, destaca-se o equilíbrio entre o suprimento de carboidratos fibrosos e não-fibrosos. A superioridade da dieta com caroço de algodão, quanto à eficiência de síntese microbiana, pode estar relacionada ao perfil da fração fibrosa nesse suplemento, a qual proporciona maior estímulo à mastigação, contribuindo para aumento da produção de saliva e diluição do conteúdo ruminal, aumentando a taxa de passagem do líquido e o escape de microrganismos. Segundo Valadares Filho et al. (2006a), a taxa de passagem é um dos fatores que influenciam os padrões de fermentação ruminal e a síntese microbiana.

De acordo com Nocek \& Russell (1988), a eficiência do crescimento microbiano depende da partição da energia em mantença e crescimento e está inversamente relacionada ao tempo de permanência dos microrganismos no ambiente ruminal. Nesse sentido, quanto mais rápida a passagem de microrganismos, menor a utilização de energia para mantença e maior a eficiência de síntese microbiana.

Considerando que $77,0 \%$ do nitrogênio total era oriundo da uréia, que a palma forrageira e o bagaço de cana-de-açúcar apresentam baixos teores protéicos e que a proteína do bagaço encontra-se quase totalmente indisponível, pode-se inferir que a alta concentração de carboidratos não-fibrosos na palma facilitou a incorporação do nitrogênio da uréia na proteína microbiana, principal fonte de proteína metabolizável para o animal hospedeiro, proporcionando eficiência de síntese microbiana de 105,0 $\mathrm{gPBmic} / \mathrm{kg}$ de NDT consumido, semelhante $(\mathrm{P}>0,05)$ à das dietas com farelo de algodão ou farelo de trigo. O NRC (2001) propõe o valor de $130 \mathrm{gPBmic} / \mathrm{kg}$ de NDT consumido, porém, Valadares Filho et al. (2006a) recomendaram, a partir de dados de pesquisas realizadas no Brasil, a utilização de 120 gPBmic/kg de NDT como referência para eficiência de síntese microbiana em condições tropicais, inferior ao de $130 \mathrm{gPBmic} / \mathrm{kg}$ de NDT sugerido pelo NRC (2001).

De acordo com o NRC (1996), a proteína microbiana pode contribuir com 50,0 a 100,0\% das exigências de proteína metabolizável requerida por bovinos de corte. Detmann et al. (2005) ressaltaram que fermentações extensas de carboidratos podem ocorrer, mas resultam em baixo crescimento microbiano caso os compostos nitrogenados sejam fornecidos de forma inadequada. Em situações de elevada participação do nitrogênio não-protéico sobre a proteína bruta da dieta basal, com limitação da fração protéica degradada no rúmen de natureza orgânica (aminoácidos e peptídeos), o desempenho animal pode ser comprometido.

Segundo Ipharraguerre \& Clark (2005), a resposta à suplementação protéica é variável, e parte dessa variação é explicada pelas diferentes fontes de proteína na dieta, pela proporção e origem da proteína não-degradada no rúmen, pelo efeito da proteína não-degradável sobre o fluxo ruminal de proteína microbiana e pela composição em aminoácidos da fonte de proteína não-degradável. Esses autores observaram redução na passagem do nitrogênio de origem microbiana para o intestino delgado quando o farelo de soja foi substituído por fontes de proteína não-degradável, o que pode justificar o comportamento observado neste estudo para os animais alimentados com rações com o farelo de algodão. O farelo de algodão é uma fonte de proteína disponível pós-rúmen, uma vez que aproximadamente $17,0 \%$ da proteína bruta deste suplemento é representada pela fração protéica $\mathrm{B}_{3}$ (Valadares Filho et al., 2006b). O farelo de soja, por sua vez, é uma fonte de proteína disponível aos microrganismos ruminais, na qual aproximadamente $90,0 \%$ da proteína bruta é composta pelas frações protéicas $\mathrm{B}_{1}$ e $\mathrm{B}_{2}$ e apenas 2,0\% é representada pela fração protéica $B_{3}$ (Valadares Filho et al., 2006b), o que pode melhorar a síntese microbiana.

A adição de proteína verdadeira degradável à dieta pode melhorar a produção microbiana. Neste estudo, esperava-se que a introdução de fontes de aminoácidos disponíveis no rúmen melhorasse a síntese e a eficiência de síntese microbiana, o que só foi evidenciado com a suplementação com o farelo de soja ou com o caroço de algodão.

\section{Conclusões}

A associação da palma forrageira ao bagaço de canade-açúcar e à uréia, sem o uso de suplementos e nas proporções estudadas, permite eficiência de síntese microbiana bastante satisfatória. A suplementação com 
farelo de soja e farelo de algodão aumenta a excreção de compostos nitrogenados e a suplementação com caroço de algodão melhora a síntese de proteína microbiana, portanto, é a mais recomendada.

\section{Agradecimentos}

Ao Instituto Agronômico de Pernambuco (IPA), pela utilização dos animais e instalações; à UFRPE, pela parceria UFRPE/UFV; e à FAPEMIG, pela concessão da bolsa de estudos.

\section{Literatura Citada}

BUTLER, W.R.; CHERNEY, D.J.R.; ELROD, C.C. Milk urea nitrogen (MUN) analysis: field trial results on conception rates and dietary inputs. In: CORNELL PROCEEDINGS CONFERENCE, 1., 1995, Ithaca. Proceedings... Ithaca: Cornell University, 1995. p.89-95.

CAVALCANTE, M.A.B.; PEREIRA, O.G.; VALADARES FILHO, S.C. et al. Níveis de proteína bruta em dietas para bovinos de corte: parâmetros ruminais, balanço de compostos nitrogenados e produção de proteína microbiana. Revista Brasileira de Zootecnia, v.35, n.1, p.203-210, 2006.

CHEN, X.B.; GOMES, M.J. Estimation of microbial protein supply to sheep and cattle based on urinary excretion of purine derivatives - an overview of technical details. Bucksburnd: Rowett Research Institute, 1992. 21p. (Occasional publication).

CHIZZOTTI, M.L. Avaliação da casca de algodão para novilhos de origem leiteira e determinação da excreção de creatinina e produção de proteína microbiana em novilhas e vacas leiteiras. 2004. 132f. Dissertação (Mestrado em Zootecnia) - Universidade Federal de Viçosa, Viçosa, MG, 2004.

CHIZZOTTI, M.L.; VALADARES FILHO, S.C.; VALADARES, R.F.D. et al. Consumo, digestibilidade e excreção de uréia e derivados de purinas em novilhas de diferentes pesos. Revista Brasileira de Zootecnia, v.35, n.4, p.1813-1821, 2006 (supl.).

DETMANN, E.; PAULINO, M.F.; VALADARES FILHO, S.C. et al. Níveis de proteína em suplementos para terminação de bovinos em pastejo durante o período de transição seca/águas: digestibilidade aparente e parâmetros do metabolismo ruminal e dos compostos nitrogenados. Revista Brasileira de Zootecnia, v.34, n.4, p.1380-1391, 2005.

ENCARNAÇÃO, C.R.F. Observações meteorológicas e tipos climáticos das unidades e campos experimentais da empresa IPA. Recife: Empresa Pernambucana de Pesquisa Agropecuária, 1980. 110p.

FUJIHARA, T.; ØRSKOV, E.R.; REEDS, P.J. et al. The effect of protein infusion on urinary excretion of purine derivates in ruminants nourished by intragastric nutrition. Journal of Agriculture Science, v.109, n.1, p.7-12, 1987.

IPHARRAGUERRE, I.R.; CLARK, J.H. Impacts of the sources and amount of crude protein on the intestinal supply of nitrogen fractions and performance of dairy cows. Journal of Dairy Science, v.88, p.E22-E37, 2005 (E. Suppl).

ÍTAVO, L.C.V.; VALADARES FILHO, S.C.; SILVA, F.F. et al. Produção microbiana e parâmetros ruminais de novilhos alimentados com dietas contendo vários níveis de concentrado. Revista Brasileira de Zootecnia, v.31, n.3, p.1553-1561, 2002 (supl.).

LEÃO, M.I. Metodologias de coletas de digestas omasal e abomasal em novilhos submetidos a três níveis de ingestão: consumo, digestibilidade e produção microbiana.
2002. 57f. Tese (Doutorado em Ciência Animal) - Universidade Federal de Minas Gerais, Belo Horizonte, 2002.

MAGALHÃES, K.A.; VALADARES FILHO, S.C.; VALADARES, R.F.D. et al. Produção de proteína microbiana, concentração plasmática de uréia e excreções de uréia em novilhos alimentados com diferentes níveis de uréia ou casca de algodão. Revista Brasileira de Zootecnia, v.34, n.4, p.1400-1407, 2005.

NATIONAL RESEARCH COUNCIL - NRC. Nutrient requirements of beef cattle. 7.ed. Washington, D.C.: 1996. 242p.

NATIONAL RESEARCH COUNCIL - NRC. Nutrient requirements of dairy cattle. 7.ed. Washington: D.C.: 2001. 363p.

NOCEK, J.E.; RUSSELL, J.B. Protein and energy as an integrated system. Relation of ruminal protein and carbohydrates availability to microbial synthesis and milk production. Journal of Dairy Science, v.71, n.8, p.2070-2107, 1988.

ORELLANA BOERO, P.; BALCELLS, J.; MARTÍN-ORÚE, S.M. et al. Excretion of purine derivates in cows: endogenous contribution and recovery of exogenous purine bases. Livestock Production Science, v.68, n.2-3, p.243-250, 2001.

PEREZ, J.F.; BALCELLS, J.; GUADA, J.A. et al. Determination of rumen microbial-nitrogen production in sheep: a comparison of urinary purine excretion with methods using $15 \mathrm{~N}$ and purine bases as markers of microbial-nitrogen entering the duodenum. British Journal of Nutrition, v.75, n.5, p.699-709, 1996.

RENNÓ, L.N.; VALADARES FILHO, S.C; PAULINO, M.F. et al. Níveis de uréia na ração de novilhos de quatro grupos genéticos: parâmetros ruminais, uréia plasmática e excreções de uréia e creatinina. Revista Brasileira de Zootecnia, v.37, n.3, p.556562, 2008

RENNÓ, L.N.; VALADARES, R.F.D.; VALADARES FILHO, S.C. et al. Concentração plasmática de uréia e excreções de uréia e creatinina em novilhos. Revista Brasileira de Zootecnia, v.29, n.4, p.1235-1243, 2000.

SILVA, D.J.; QUEIROZ, A.C. Análise de alimentos (métodos químicos e biológicos). 3.ed. Viçosa, MG: Editora UFV, 2002. 235p.

TEIXEIRA, R.M.A.; CAMPOS, J.M.S.; VALADARES FILHO, S.C. et al. Balanço de compostos nitrogenados e produção de proteína microbiana em novilhas leiteiras alimentadas com casca de café em substituição à silagem de milho. Revista Brasileira de Zootecnia, v.36, n.5, p.1691-1698, 2007 (supl.).

UNIVERSIDADE FEDERAL DE VIÇOSA - UFV. SAEG - Sistema de análises estatísticas e genéticas. Versão 8.0. Viçosa, MG: 1998. 150p.

VALADARES, R.F.D.; VALADARES FILHO, S.C.; GONÇALVES, L.C. et al. Níveis de proteína em dietas de bovinos. 4. Concentrações de amônia ruminal e uréia plasmática e excreções de uréia e creatinina. Revista Brasileira de Zootecnia, v.26, n.6, p.1270-1278, 1997.

VALADARES, R.F.D.; BRODERICK, G.A.; VALADARES FILHO, S.C. et al. Effect of replacing alfalfa with high moisture corn on ruminal protein synthesis estimated from excretion of total purine derivatives. Journal of Dairy Science, v.8, n.12, p.2686-2696, 1999.

VALADARES FILHO, S.C.; VALADARES, R.F.D. Recentes avanços em proteína na nutrição de vacas leiteiras. In: SIMPÓSIO INTERNACIONAL DE BOVINOCULTURA DE LEITE, SINLEITE, 2., 2001, Lavras. Anais... Lavras: Universidade Federal de Lavras, 2001. p.228-243.

VALADARES FILHO, S.C.; MAGALHÃES, K.A.; ROCHA JR., V.R. et al. Tabelas brasileiras de composição de alimentos para bovinos. 2.ed. Viçosa, MG: Gráfica Suprema, 2006a. 329p.

VALADARES FILHO, S.C.; PAULINO, P.V.R.; MAGALHÃES, K.A et al. Exigências nutricionais de zebuínos e tabelas de composição de alimentos - BR Corte. 1.ed. Viçosa, MG: Gráfica Suprema, 2006b. 142p.

Van SOEST, P.J. Nutritional ecology of the ruminant. 2.ed. Ithaca: Cornell, 1994. 476p.

VERBIC, J.; CHEN, X.B.; MACLEOD, N.A. et al. Excretion of purine derivatives by ruminants. Effect of microbial nucleic acid infusion on purine derivative excretion by steers. Journal of Agricultural Science, v.114, n.3, p.243-248, 1990. 